\title{
Expression of the long (OB-RB) and short (OB-RA) forms of the leptin receptor throughout the oestrous cycle in the mature rat ovary
}

\author{
P. S. Duggal ${ }^{1}$, S. R. Weitsman², D. A. Magoffin² \\ and R. J. Norman ${ }^{1 *}$ \\ ${ }^{1}$ Reproductive Medicine Unit, Department of Obstetrics and Gynaecology, \\ The University of Adelaide, The Queen Elizabeth Hospital, Woodville 5011, SA, Australia; \\ and ${ }^{2}$ Department of Obstetrics and Gynaecology, Cedars-Sinai Burns and Allen Research \\ Institute, Los Angeles, CA, USA
}

Leptin is secreted by adipocytes and exerts its effects by interacting with the long form of the leptin receptor, OB-RB. The leptin protein and leptin receptors have been localized in the ovary, and acute leptin treatment directly inhibits ovulation in the rat ovary. It was hypothesized that expression of the leptin receptor gene varies throughout the oestrous cycle to modulate the sensitivity of the ovary to leptin. In this study, expression of genes for the long and short isoforms of the leptin receptor in the adult ovary was investigated at different stages of the rat oestrous cycle. Vaginal cytology was used to determine the stage of the oestrous cycle. Ovaries were collected and RNA was extracted for real-time RT-PCR analysis of leptin receptor gene expression. OB-RB gene expression was low in prooestrus ( $3.13 \pm 0.18 \mathrm{fg}$ RNA per $\mu \mathrm{g}$ total DNA) and dioestrus II $(2.52 \pm 0.19$ fg RNA per $\mu \mathrm{g}$ total DNA $)$ of the oestrous cycle, whereas expression was high in oestrus $(5.9 \pm 0.27 \mathrm{fg}$ RNA per $\mu \mathrm{g}$ total DNA) and dioestrus I $(4.6 \pm 0.24 \mathrm{fg}$ RNA per $\mu \mathrm{g}$ total DNA $)(P<0.001)$. Expression of the gene for the short form of the leptin receptor (OB-RA) was at a maximum in dioestrus I $(65.5 \pm 0.8 \mathrm{fg}$ RNA per $\mathrm{ng}$ total DNA), high in oestrus $(39.0 \pm 0.8 \mathrm{fg}$ RNA per $\mathrm{ng}$ total DNA) and low at pro- oestrus $(5.0 \pm 0.2$ fg RNA per $n g$ total DNA) and dioestrus II $(1.1 \pm 0.09$ fg RNA per $n g$ total DNA $)(P<0.001)$. Plasma oestradiol concentrations $\left(\mathrm{pg} \mathrm{ml}^{-1}\right)$ were highest at pro-oestrus $(19.38 \pm 1.3)$, and similar at the remaining three stages studied (oestrus: $13.7 \pm 1.9$; dioestrus I: $12.4 \pm 1.0$; dioestrus II: $10.3 \pm 0.9) \quad(P<0.05)$. Plasma progesterone concentrations $\left(\mathrm{ng} \mathrm{ml}^{-1}\right)$ were higher in the luteal phases of the oestrous cycle (dioestrus I: $18.6 \pm 2.3$; dioestrus II: $14.7 \pm 2.5)$ than during pro-oestrus $(5.12 \pm$ $0.6)$ and oestrus $(5.9 \pm 0.8)(P<0.05)$. Plasma leptin concentrations were detectable only in pro-oestrus $(0.35 \pm$ $0.05 \mathrm{ng} \mathrm{ml}^{-1}$ ) and were below the detection limit of the assay at other stages of the oestrous cycle. In summary, mRNA content for the long and short isoforms of the leptin receptor is lower in pro-oestrus and dioestrus II than in oestrus and dioestrus I of the rat oestrous cycle. The fluctuations in leptin receptor mRNA content may be a response to the concentrations of circulating steroid hormones and leptin. This research supports the initial hypothesis and shows that ovarian leptin receptor concentrations vary throughout the oestrous cycle in response to the changing environment of the ovary.

\section{Introduction}

Leptin is an adipocyte-derived hormone that plays an important role in the regulation of body fat mass and food intake. Two main sites of leptin action relating to the reproductive system are the brain and the ovary. The importance of the leptin protein in the brain has been well documented (Campfield et al., 1996; McCowen et al., 1998). Recent studies have demonstrated the significance of leptin in the regulation of reproductive processes in the human and rat ovary (Cioffi et al., 1997; Agarwal et al., 1999; Barkan et al.,

*Correspondence

Email: robert.norman@adelaide.edu.au
1999; Cunningham et al., 1999; Kitawaki et al., 1999; Zachow et al., 1999) and the inhibitory effect of acute leptin treatment on ovulation in rats (Duggal et al., 2000).

Leptin and the secretion of steroid hormones appear to be directly linked. Leptin concentrations in peripheral blood samples vary throughout the human menstrual cycle (Licinio et al., 1998; Lukaszuk et al., 1998; Messinis et al., 1998): leptin concentrations peak in the luteal phase in a similar manner to oestradiol and progesterone concentrations (Slieker et al., 1996; Lukaszuk et al., 1998). Leptin gene expression in fat decreases with ovariectomy (Yoneda et al., 1998), whereas leptin stimulates the production of oestrogen in periovarian fat and increases the production of progesterone and testosterone in the ovary (Cannady et al., 
2000). Therefore, the variations in peripheral leptin concentrations throughout the menstrual cycle may alter the responsiveness of the ovary to leptin.

There is a short regulatory loop controlling leptin receptor mRNA synthesis in the brain. Six isoforms of the leptin receptor have been identified. The long isoform of the leptin receptor (OB-RB) is believed to be the main isoform responsible for leptin signal transduction. It has been suggested that the short form of the leptin receptor (OB-RA) is a transporter molecule for leptin (Stephens and Caro, 1998) that promotes leptin stability; however, its exact function is still unclear. OB-RB gene expression (Cioffi et al., 1997; Spicer and Francisco, 1997; Zachow et al., 1999) and the OB-RB receptor (Cioffi et al., 1997; Karlsson et al., 1997; Spicer and Francisco, 1998; Ruiz-Cortes et al., 2000) have been localized in granulosa and theca cells of the ovary, whereas OB-RA expression and localization is ubiquitous. Several lines of evidence indicate that the leptin receptors are regulated by, and respond to, changes in circulating steroid hormones and leptin concentrations. Firstly, leptin receptors are differentially expressed in the hypothalamus at different stages of the oestrous cycle. The lowest concentration of total leptin receptor transcripts occurs in the choroid plexus at pro-oestrus, corresponding inversely to the highest concentration of oestradiol in the 4 day oestrous cycle of rats (Bennett et al., 1999). Secondly, leptin concentrations vary with the duration of the photoperiod and with food deprivation (Saladin et al., 1995; Caro et al., 1996), and studies in Siberian hamsters have shown that leptin receptor mRNA expression also varies in response to these factors (Mercer et al., 2000). Thirdly, leptin infusion into the brain results in an increase in leptin receptor transcripts (Bennett et al., 1998, 1999). Finally, leptin-deficient mice (Mercer et al., 1997) and fasting rats (Bennett et al., 1998) have increased leptin receptor gene expression in the brain, and leptin treatment in these animals reduces the concentration of leptin receptor transcripts (Mercer et al., 1997). This feedback loop also appears to work in the opposite direction in adipose tissue, as reduced copy number for the functional leptin receptor results in a diminished feedback signal to the leptin gene (Zhang et al., 1997). Therefore, on the basis of studies in other organs, the concentration of leptin receptors may fluctuate in the ovary relative to circulating concentrations of steroids and leptin.

There is a species difference between rodents and humans in the circulating concentrations of leptin throughout the reproductive cycle: unlike the situation in humans, leptin concentrations remain constant throughout the oestrous cycle in mice (Chehab et al., 1997) and rats (Bennett et al., 1999). It was hypothesized that ovarian leptin receptor gene expression varies throughout the oestrous cycle in rats in response to the changing hormonal environment of the ovary, thus modulating ovarian sensitivity to the leptin protein. The purpose of the present study was to determine the relationship between plasma leptin concentrations, steroid hormone secretion and leptin receptor (OB-RB and OB-RA) gene expression at the various stages of the oestrous cycle using the highly sensitive technique of real-time RT-PCR.

\section{Materials and Methods}

\section{Animals}

Pubertal female Sprague-Dawley rats (from the University of Adelaide colony) weighing approximately $80 \mathrm{~g}$ were maintained under controlled conditions of light (14 h light:10 h dark), temperature and humidity, with free access to pelleted food ( $21 \%$ protein, $6.9 \%$ fat, $5.4 \%$ fibre: equivalent to $34.4 \mathrm{kcal} \mathrm{g}^{-1}$ ) and water. The rats were allowed 5 days to acclimatize to their new surroundings and then vaginal smears (Bronson et al., 1966) were performed (between 09:00 and 11:00 h) for three consecutive oestrous cycles. Only mature, ovulating animals with three consecutive 4 day oestrous cycles were included in the study. Animals were handled in accordance with the Australian code of practice for the care and use of animals for scientific purposes, and the animal ethics committees of both The Queen Elizabeth Hospital and The University of Adelaide approved all experiments.

\section{Tissue collection, RNA and DNA isolation}

Given that leptin protein circulates in a diurnal pattern in rodents (Mistlberger et al., 1998; Pickavance et al., 1998) and rodents are nocturnal foragers, all animals were killed between 11:00 and 13:00 h, a time that is not associated with eating in rats. Rats were killed by s.c. administration of a mixture of the anaesthetic Ketamil (100 mg ketamine $\mathrm{ml}^{-1}$; Troy Laboratories Pty Ltd, NSW) and the muscle relaxant Rompun (20 mg xylazine $\mathrm{ml}^{-1}$; Bayer AG, Leverkusen). The ovaries and the attached oviducts were dissected out, placed into diethyl pyrocarbonate-treated water and the ampulla region of the oviducts (with or without ovulated oocytes), ovarian bursa and fat were removed. Left and right ovaries were weighed, frozen separately in liquid nitrogen and stored at $-80^{\circ} \mathrm{C}$. RNAse-free conditions were maintained during the collection of tissues. RNA and DNA were isolated using Tri Reagent, the RNA, DNA and protein isolation reagent (Molecular Research Center Inc., Cincinnati, $\mathrm{OH})$, in accordance with the manufacturer's protocol (1995). RNA and DNA were quantified using a fluorometer (Turner Designs, Sunnyvale, CA) as described in the manufacturer's protocol, using RiboGreen ${ }^{\mathrm{TM}}$ RNA quantitation reagent and PicoGreen ${ }^{\circledR}$ dsDNA quantitation reagent kits (Molecular Probes, Eugene, OR), respectively.

\section{Reverse transcription of $R N A$}

A master mix containing $1 \times$ PCR buffer II (Perkin Elmer, Boston, MA), $50 \mathrm{nmol}$ of each dNTP (Gibco BRL, Rockville,

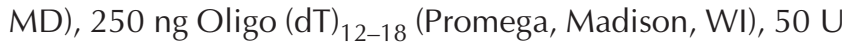
RNasin $^{\circledR}$ ribonuclease inhibitor (Promega), $250 \mathrm{nmol}$ $\mathrm{MgCl}_{2}$ (Perkin Elmer), $500 \mathrm{U}$ M-MLV reverse transcriptase (Gibco BRL) and $2 \mu \mathrm{l}$ RNA was added to a final reaction 
volume of $50 \mu \mathrm{l}$. Reactions were added to a 96-well plate (Perkin Elmer), incubated for $30 \mathrm{~min}$ at $37^{\circ} \mathrm{C}$ and $5 \mathrm{~min}$ at $95^{\circ} \mathrm{C}$ in a thermal cycler (Perkin Elmer) and then stored immediately at $-20^{\circ} \mathrm{C}$ until the $\mathrm{PCR}$ reaction. Both negative (no RNA in the RT reaction) and positive (RT-check ${ }^{\mathrm{TM}}$; Ambion Inc., Austin, TX) controls were included in the RT reaction. Total DNA from ovarian tissue was quantified to control for tissue-to-tissue variation.

\section{Generation of standard $O B-R B$ and $O B-R A D N A$ in TOPO TA cloning vector}

Primers used by Zachow et al. (1999), synthesized by Gibco BRL, were used to amplify both the long and short isoforms of the leptin receptor. A common forward primer (5'-ATGAAGTGGCTTAGAATCCCTTCG-3') for both OB-RB and OB-RA was used. The reverse primers for the long and short isoforms were 5'-ATATCACTGATTCTGCATGCT-3' and 5'-TACTTCAAAGAGTGTCCGCTC-3', respectively. A PCR master mix containing $1 \times$ PCR buffer, $1.5 \mathrm{mmol}$ $\mathrm{MgCl}_{2} \mathrm{I}^{-1}, 0.2 \mathrm{mmol} \mathrm{I}^{-1}$ of each dNTP, $400 \mathrm{nmol} \mathrm{I}^{-1}$ of each OB-RB primer or $200 \mathrm{nmol} \mathrm{I}^{-1}$ of each OB-RA primer, $2.5 \mathrm{U}$ Taq Polymerase (Perkin Elmer) and $2 \mu \mathrm{l}$ of the cDNA (to a final volume of $50 \mu \mathrm{l}$ ) was placed in a thermal cycler and a two-step PCR protocol (denaturing at $94^{\circ} \mathrm{C}$ and annealing at $55^{\circ} \mathrm{C}$ for $30 \mathrm{~s}$ each) of 40 cycles was applied. A single band of the expected size (346 bp for OB-RA and $375 \mathrm{bp}$ for OBRB) was visualized using gel electrophoresis and confirmed by enzymatic digestion and direct sequence. The gel bands were excised and the DNA purified using a QIAprep gel extraction kit (QIAgen, Valencia, CA). Both DNA fragments were inserted into TOPO TA cloning vectors (Invitrogen, Carlsbad, CA), transformed into TOP10F' cells and plated on Luria Bertoni agar plates with $50 \mu \mathrm{g}$ ampicillin $\mathrm{ml}^{-1}$ (Fisher Scientific, Fair Lawn, NJ), according to manufacturer's instructions (1999). Positive clones (white colonies) were considered to have an insert in the TOPO TA cloning vector and these colonies were cultured overnight at $37^{\circ} \mathrm{C}$ in LB media with $50 \mu \mathrm{g}$ ampicillin $\mathrm{ml}^{-1}$. Vector insert DNA was extracted using QIAprep spin miniprep kits (QIAgen) and the presence of the insert was identified by EcoRV restriction enzyme digestion (Gibco BRL) and visualized using gel electrophoresis. Vector inserts were linearized using Kpnl (Promega) for OB-RB and HindIII (Gibco BRL) for OBRA. The concentration of DNA was quantified and dilutions prepared for the synthesis of standards for real-time PCR.

\section{Real-time PCR}

A common hybridization probe (Operon, Alameda, CA) was constructed, 5'-CCTTGTGCCCAGGAACAATTCAAGG$3^{\prime}$, with the reporter fluorochrome (6-carboxyfluorescein; 6-FAM) at the 5' end and a quencher fluorochrome (6-carboxy-tetramethyl-rhodamine; TAMRA) at the 3' end. The probe had a melting temperature $\left(T_{\mathrm{m}}\right)$ of approximately $15^{\circ} \mathrm{C}$ above that of the PCR primers and had four additional base pairs at the $3^{\prime}$ end to promote a hairpin structure of the hybridization oligonucleotide to minimize background fluorescence. The PCR master mix consisted of: $1 \times$ PCR buffer, $1.5 \mathrm{mmol} \mathrm{MgCl}_{2} \mathrm{I}^{-1}, 0.2 \mu \mathrm{mol} \mathrm{I^{-1 }}$ of each dNTP, $400 \mathrm{nmol} \mathrm{I}^{-1}$ of primers for OB-RB detection, $200 \mathrm{nmol} \mathrm{^{-1 }}$ of primers for OB-RA detection and $2.5 \mathrm{U}$ platinum Taq DNA polymerase (all from Gibco BRL). Ten microlitres of the RT reaction mixture was added to the appropriate wells, in duplicate. Hybridization oligonucleotide (500 nmol ${ }^{-1}$ ) was added to each well of the 96-well I-cycler plate (Bio-Rad, Hercules, CA) under low intensity light conditions. Real-time RT-PCR was carried out using the two-step procedure described above and data were recorded by the Bio-Rad I-cycler program (Bio-Rad).

\section{Progesterone, oestradiol and leptin assays}

Immediately before the animals were killed, a blood sample was collected from each animal by cardiac puncture, for plasma progesterone and oestradiol and leptin analyses. Blood was transferred to a lithium heparin separator tube (Vacuette Greiner Labortechnik, Kremsmunster, Bad Hollestr) and centrifuged at $13000 \mathrm{~g}$ for $10 \mathrm{~min}$ at $4^{\circ} \mathrm{C}$. The upper clear layer was stored at $-80^{\circ} \mathrm{C}$ before assaying. All assay kits were purchased from DSL Inc. (Webster, TX) and analyses performed according to the manufacturer's instructions. Progesterone (DSL-3400) and oestradiol (DSL-4400) concentrations in rat plasma samples were analysed using radioimmunoassay kits. Leptin (DSL-10-24100) concentrations were measured by using an Active $^{\mathrm{TM}}$ murine leptin ELISA kit, which is sensitive for both rat and mouse plasma leptin. The minimum detection limits of the progesterone, oestradiol and leptin assays were $0.09 \mathrm{ng} \mathrm{ml}^{-1}, 4.6 \mathrm{pg} \mathrm{ml}^{-1}$ and $0.04 \mathrm{ng} \mathrm{ml}^{-1}$, respectively. The intra-assay coefficient of variation for each assay was $<7 \%$. Samples for progesterone and oestradiol analysis were assayed in duplicate. The option of using $100 \mu \mathrm{l}$ in the assay was included to quantify the low concentrations of serum leptin.

\section{Statistical analyses}

Samples for analysis were assayed on a total of four I-cycler plates, with one plate dedicated for one ovary, to quantify both receptors. The inter-plate variation was $<6 \%$ and $<4 \%$ for OB-RB and OB-RA, respectively. RNA samples with threshold cycle numbers higher than the negative control values in the real-time RT-PCR assays were omitted from the study. The statistical analyses ( $n=6$ or 7 rats) were performed using the Bonferroni multiple comparisons test after significance was established using an ANOVA. In all studies, statistical significance was accepted when the $P$ value was $<0.05$.

\section{Results}

\section{Generation of standard $O B-R B$ and $O B-R A D N A$ in TOPO TA cloning vector}

Fragments of the long and short isoforms of the leptin receptor were generated by PCR using the appropriate 

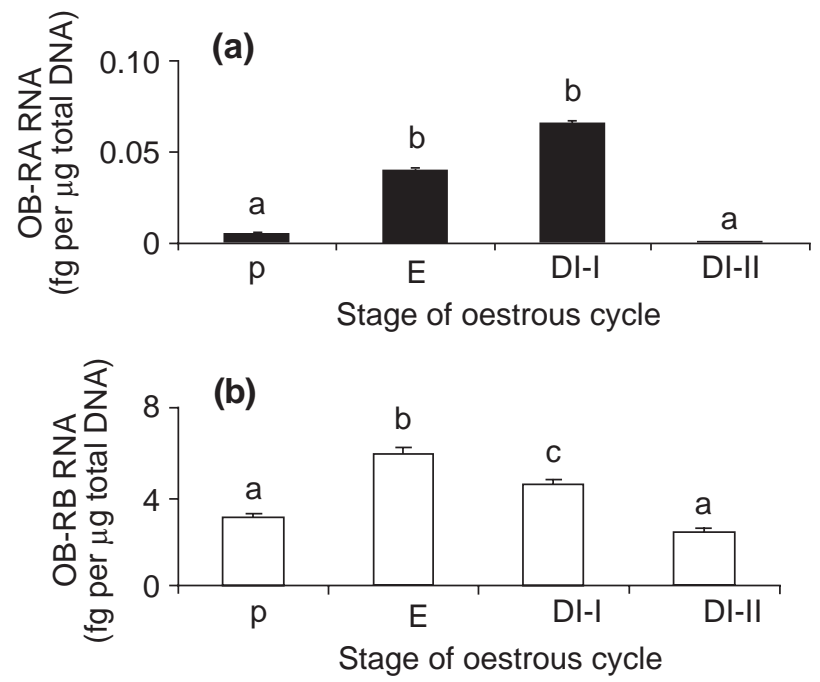

Fig. 1. Standard concentration of RNA (fg or $10^{-15} \mathrm{~g}$ ) for the (a) short (OB-RA) and (b) long (OB-RB) form of the leptin receptor in the rat ovary throughout the oestrous cycle. The oestrous cycle of mature Sprague-Dawley rats was determined by vaginal cytology (P: pro-oestrus; E: oestrus; DI-I: dioestrus I; DI-II: dioestrus II). Ovaries were collected for RNA extraction and processed for realtime RT-PCR analyses. Data are expressed as the mean \pm SEM standard concentration of RNA for each receptor, from both ovaries. Different letters indicate significant differences between groups $(P<0.05)$.

primers and cloned into the TOPO TA cloning vectors. The identity of the inserts was confirmed by direct sequencing and restriction mapping. The vector inserts were linearized for the preparation of standards for OB-RB and OB-RA. Standards were diluted to provide a range of concentrations to prepare a standard curve, and real-time PCR was performed. The standard curve data are expressed as the amount (fg) of insert DNA alone (from the insert vector), therefore, the results reflected the amount of full-length cDNA generated from mRNA samples. The threshold cycle, the cycle at which point the reporter dye emission intensity is above background noise, was used to determine the cycle number at which PCR amplification was in an exponential phase.

\section{Real-time RT-PCR of tissues at different stages of the oestrous cycle, $O B-R A$ and $O B-R B$ detection}

Real-time RT-PCR for OB-RA and OB-RB isoforms was performed to establish the expression pattern of the leptin receptor genes throughout the oestrous cycle (Fig. 1). OB-RA real-time RT-PCR analysis revealed that leptin receptor expression was high in oestrus and dioestrus I and the maximum expression was noted in dioestrus I (Fig. 1a). Real-time RT-PCR of OB-RB revealed a similar expression pattern: expression of OB-RB was highest at oestrus and dioestrus I, whereas lower expression was recorded at pro-oestrus and dioestrus II (Fig. 1b). PCR products were also visualized using gel electrophoresis to confirm the production of a single, correctly sized product. After the 40 cycles, gel electrophoresis revealed that the end quantity of the PCR products of each tube, regardless of starting concentrations, were identical. Therefore, by using realtime RT-PCR it was possible to quantify accurately the small differences among samples by analysing data in the exponential phase.

\section{Negative and positive controls}

Negative controls included omitting RNA in the RT step or omitting cDNA in the real-time RT-PCR step. Negative controls resulted in background level noise on the I-cycler PCR machine and no PCR product was visualized by gel electrophoresis. The RT-check ${ }^{\mathrm{TM}}$ kit was used as an endogenous control to test the integrity of the RT step and the amplification efficiency of the PCR. The PCR products produced in the $\mathrm{RT}_{\text {-check }}^{\mathrm{TM}}$ step were labelled with $\left[{ }^{32} \mathrm{P}\right] \mathrm{dCTP}$, visualized by gel electrophoresis and the bands were excised and counted in a scintillation counter. The radioactivity counts from the various PCR products validated that the RT step and amplification efficiency was similar from tissue to tissue $(<8 \%$ variation across all tissues). Owing to the low tube-to-tube variation, data generated from the real-time experiments required no correction. Genomic DNA was quantified in ovaries to control for variation among tissues. Data are expressed as $\mathrm{fg}$ RNA per $\mu g$ total DNA.

\section{Body weight, ovarian mass, and plasma steroid hormone} and leptin concentrations

Body weights of animals at the time of tissue removal were similar among groups (Table 1). Left and right ovaries of animals, regardless of the stage of the oestrous cycle, were of similar mass (Table 1). Plasma oestradiol concentrations (pg $\mathrm{ml}^{-1}$ ) were highest at the time of pro-oestrus $(19.38 \pm 1.3)$, and similar in the remaining three stages of the oestrous cycle studied (oestrus: $13.7 \pm 1.9$; dioestrus I: $12.4 \pm 1.0$; dioestrus II: $10.3 \pm 0.9) \quad(P<0.05$ for prooestrus versus the remaining stages studied). Plasma proges-

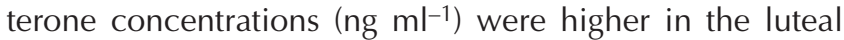
phases of the cycle (dioestrus I: $18.6 \pm 2.3$; dioestrus II: $14.7 \pm 2.5)$ than at pro-oestrus $(5.12 \pm 0.6)$ and oestrus $(5.9 \pm 0.8)(P<0.05)$. Plasma leptin concentrations were detectable only in pro-oestrus $\left(0.35 \pm 0.05 \mathrm{ng} \mathrm{ml}^{-1}\right)$ and were below the detection limit of the assay at other stages of the oestrous cycle.

\section{Discussion}

Gene expression of the long form (OB-RB) of the leptin receptor has been detected in granulosa, theca, interstitial and cumulus oophorus cells of the human ovary (Cioffi et al., 1997; Karlsson et al., 1997; Agarwal et al., 1999). The short form (OB-RA) of the leptin receptor has been detected in granulosa, theca and cumulus oophorus cells of the human ovary (Cioffi et al., 1997; Karlsson et al., 1997; Agarwal et al., 1999). In rats, OB-RA and OB-RB are 
Table 1. Body weights, ovarian masses and concentrations of serum leptin, oestradiol and progesterone in rats at different stages of the oestrous cycle

\begin{tabular}{lcccc}
\hline & Pro-oestrus & Oestrus & Dioestrus I & Dioestrus II \\
\hline Body weight $(\mathrm{g})$ & $184 \pm 13$ & $163 \pm 9$ & $152 \pm 5$ & $168 \pm 6$ \\
Ovarian mass $(\mathrm{mg})$ & $310 \pm 11$ & $262 \pm 27$ & $295 \pm 3$ & $292 \pm 2$ \\
Serum leptin $\left(\mathrm{ng} \mathrm{ml}^{-1}\right)$ & $0.35 \pm 0.05$ & $\mathrm{ND}$ & $\mathrm{ND}$ & $\mathrm{ND}$ \\
Oestradiol $\left(\mathrm{pg} \mathrm{ml} \mathrm{m}^{-1}\right)$ & $19.38 \pm 1.3^{\mathrm{a}}$ & $13.7 \pm 1.9^{\mathrm{b}}$ & $12.4 \pm 1.0^{\mathrm{b}}$ & $10.3 \pm 0.9^{\mathrm{b}}$ \\
Progesterone $\left(\mathrm{ng} \mathrm{ml}^{-1}\right)$ & $5.12 \pm 0.6^{\mathrm{a}}$ & $5.9 \pm 0.8^{\mathrm{a}}$ & $18.6 \pm 2.3^{\mathrm{b}}$ & $14.7 \pm 2.5^{\mathrm{b}}$ \\
\hline
\end{tabular}

All measurements reported are at the time of tissue collection.

Values are mean \pm SEM per animal $(n=6-7)$.

Different letters indicate significant differences between groups $(P<0.05)$.

ND: not detected.

expressed in granulosa cells, but expression of only OB-RA is detectable in theca cells of hypophysectomized rats (Zachow et al., 1999). However, the expression of OB-RA and OB-RB in the ovary at different times of the oestrous cycle has not been quantified in any species. The current study was designed to investigate the direct effect of the stage of the oestrous cycle on leptin receptor (OB-R) expression in the rat ovary using the specific and quantitative technique of real-time RT-PCR.

This study demonstrates that OB-R expression varies in response to the changing environment of the ovary. The onset of oestrus and dioestrus I was correlated with an increase in the expression of OB-RA and OB-RB genes, and lower expression was observed at pro-oestrus and dioestrus II. The experimental design allowed specific identification of the natural expression patterns of the ovarian OB-R genes in response to normal fluctuations of steroid hormones and the leptin protein, throughout the oestrous cycle. With this design it was possible to focus on the ovary while it remained an intact unit with the hypothalamic-pituitary-ovarian axes, and the findings indicate that OB-R gene expression throughout the oestrous cycle responds to cyclical changes.

There is controversy with regards to the interaction between leptin and steroid hormones. Some studies have shown that oestradiol does not affect leptin secretion (Haffner et al., 1997; Castracane et al., 1998). However, several other studies have reported an interaction between leptin and steroid hormones in the human menstrual cycle (Hardie et al., 1997; Licinio et al., 1998; Lukaszuk et al., 1998; Mannucci et al., 1998; Messinis et al., 1998, 1999; Teirmaa et al., 1998; Gower et al., 2000). This research prompted measurement of leptin and steroid hormone concentrations in rats throughout the oestrous cycle in the present study. The results revealed that steroid hormone concentrations vary throughout the oestrous cycle and that maximum oestradiol concentrations occur at pro-oestrus (Butcher et al., 1974; Kalra and Kalra, 1974; Bennett et al., 1999). It has been proposed that leptin can regulate oestradiol oscillations in humans (Licinio et al., 1998) and that leptin gene expression is regulated by ovarian steroid hormones: ovariectomized rats have lower ob gene ex- pression in fat (Yoneda et al., 1998; Machinal et al., 1999). In support of previous research, the present study showed that leptin concentrations are at a maximum at pro-oestrus, a time when oestradiol is at its peak. Research indicates that, after an increase in oestradiol at pro-oestrus, the amount of OB-R transcript decreases in the rat choroid plexus (Bennett et al., 1999). Results from the present study show that this pattern of expression is also present in the ovary. OB-R mRNA concentrations increased in oestrus and dioestrus I after the oestradiol surge, and decreased again in dioestrus II, immediately before the oestradiol surge at prooestrus. The results indicate that oestradiol may be an important factor in fluctuations of leptin and OB-R at prooestrus. Studies on pig ovaries have shown that OB-R expression increases with maximum progesterone concentrations (Ruiz-Cortes et al., 2000). Leptin has a stimulatory effect on luteal function in pigs: leptin mRNA and protein expression increases with progesterone accumulation in vitro (Murphy and Dobias, 1999; Pescador et al., 1999). Therefore, it was hypothesized that leptin concentrations vary with progesterone concentrations during the oestrous cycle. In the present study, OB-R content was at a maximum in stages of the oestrous cycle anticipatory of maximum progesterone concentrations (oestrus and dioestrus I) and decreased markedly after high progesterone concentrations.

This study analysed OB-R expression in whole ovarian tissue; therefore, the findings relate to the change in OB-R expression in the ovary as a whole. It is possible that luteal cells, endothelial cells and leucocytes contribute to the differences in OB-R expression observed in oestrus and dioestrus I. The results presented for oestrus and dioestrus I are from a time after ovulation and development of corpora lutea. Owing to the changing physiology of the ovary, with granulosa cells becoming luteal cells, the increase in the content of OB-R transcripts probably leads to increases in intact OB-R protein. OB-R expression and OB-R gene expression increase in pig granulosa cells as they luteinize (Ruiz-Cortes et al., 2000); therefore, the findings of the present study are in agreement with previous research and support the hypothesis that luteinization in the ovary promotes an increase in OB-R. Our laboratory has located dense staining for OB-R in the theca-luteal layer in mouse 
corpora lutea (Ryan et al., 2002). The role of leptin in angiogenesis (Bouloumie et al., 1998) may also provide an explanation for the increase in OB-R at oestrus and dioestrus I, as luteinization results in neovascularization in the ovary due to ovulation at oestrus. Leucocytes and cytokines are important components of the ovulatory cascade and infiltrate the ovary at ovulation (Brannstrom and Norman, 1993). OB-R has been identified on leucocytes (Gainsford et al., 1996; Lord et al., 1998; Santos-Alvarez et al., 1999), and the contribution of these cells to the total expression of OB-R in the ovary expression cannot be dismissed. Whether the increase in OB-R arises as a result of the influx of leucocytes at ovulation remains to be defined.

In the present study, leptin concentrations were detectable only in pro-oestrus and not at the other stages of the oestrous cycle. Other researchers have reported unchanged circulating leptin concentrations throughout the oestrous cycle in mice (Chehab et al., 1997) and rats (Bennett et al., 1999). The reason for the discrepancy between the findings may be attributed to the strain of the animal or the assay technique used (radioimmunoassay versus ELISA). In the present analysis, a larger volume of serum was used in the leptin assay, in an attempt to detect low concentrations of leptin. Future work in this laboratory may clarify leptin concentrations throughout the oestrous cycle in this strain of rat.

Although previous research (Duggal et al., 2000) demonstrated that excessive leptin is inhibitory to ovulation, it has also been suggested that insufficient leptin-OB-RB interaction, due to leptin resistance, results in anovulation (Schwartz et al., 1996; Cunningham et al., 1999). It is possible that, in the study Duggal et al. (2000), acute leptin administration 'programmed' the ovary to be in a postovulatory stage of the oestrous cycle. Physiologically, postovulation is a time of increased leptin action due to the increases in OB-R. Thus, in the earlier study, the response of the ovary to acute leptin administration was inhibition of ovulation. The changes in the content of OB-R throughout the oestrous cycle provides a mechanism for the regulation of normal physiological processes to allow different responses to leptin throughout the oestrous cycle, during which leptin concentrations may otherwise vary only slightly. Such a mechanism would not be unexpected given the variability in the number of receptors of other key regulators, such as the $\mathrm{LH}$ receptor, in granulosa cells at different stages of the oestrous cycle.

In summary, the present study investigated the effect of the stage of oestrous cycle on OB-R expression in the mature rat ovary. Significant decreases were found in OB-R expression at pro-oestrus and dioestrus II, stages that are preparatory for ovulation. The stages after ovulation appeared to show an increase in OB-R gene expression. The increase in OB-RB gene expression at these stages may be a mechanism to decrease the action of leptin before ovulation while increasing the action of leptin for the corpora lutea. A simultaneous increase in OB-RA may promote the stability of leptin at times of high OB-R action, as OB-RA is thought to be a transporter molecule for leptin. The unique relationship between leptin and the ovarian axis, at a physiological level, requires clarification. Several studies have demonstrated the inhibitory action of leptin on steroidogenesis (Zachow and Magoffin, 1997; Spicer and Francisco, 1998) and ovulation (Duggal et al., 2000). Further investigations will concentrate on the effects of high concentrations of exogenous leptin and steroid hormone treatment on OB-R expression in the ovary.

The authors are grateful to Ali Murad, Keith Black's laboratory, Iqbal Munir, Hui-Wen Yen, Talia Baruth and Armine Hadar for their insightful discussions, friendship and assistance throughout this study. This research was funded by the National Health \& Medical Research Council (Australia) and NICHD (HD50759). Priya Duggal is supported by a Reproductive Medicine Laboratories Postgraduate Scholarship, University of Adelaide. Part of this research was carried out at Cedars-Sinai Burns \& Allen Research Institute and was supported by a Research Abroad Scholarship (University of Adelaide).

\section{References}

Agarwal SK, Vogel K, Weitsman SR and Magoffin DA (1999) Leptin antagonizes the insulin-like growth factor-I augmentation of steroidogenesis in granulosa and theca cells of the human ovary Journal of Clinical Endocrinology and Metabolism 84 1072-1076

Barkan D, Hui J, Dantes A, Vardimon L, Amsterdam A and Rubinstein M (1999) Leptin modulates the glucocorticoid-induced ovarian steroidogenesis Endocrinology $1401731-1738$

Bennett PA, Lindell K, Karlsson C, Robinson I, Carlsson LMS and Carlsson B (1998) Differential expression and regulation of leptin receptor isoforms in the rat brain - effects of fasting and oestrogen Neuroendocrinology 67 29-36

Bennett PA, Lindell K, Wilson C, Carlsson LMS, Carlsson B and Robinson I (1999) Cyclical variations in the abundance of leptin receptors, but not in circulating leptin, correlate with NPY expression during the oestrous cycle Neuroendocrinology 69 417-423

Bouloumie A, Drexler HCA, Lafontan M and Busse R (1998) Leptin, the product of $\mathrm{Ob}$ gene, promotes angiogenesis Circulation Research $\mathbf{8 3}$ 1059-1066

Brannstrom M and Norman RJ (1993) Involvement of leukocytes and cytokines in the ovulatory process and corpus luteum function Human Reproduction 8 1762-1775

Bronson F, Dagg C and Snell G (1966) Biology of the Laborotary Mouse 2nd Edn, Ed. EL Green, The Blakiston Division, McGraw Hill Book Co., New York

Butcher R, Collins W and Fugo N (1974) Plasma concentrations of LH, FSH, prolactin, progesterone and oestradiol $17 \beta$ throughout the 4-day oestrous cycle of the rat Endocrinology 94 1704-1708

Campfield LA, Smith FJ and Burn P (1996) The OB protein (leptin) pathway - a link between adipose tissue mass and central neural networks Hormone and Metabolic Research 28 619-632

Cannady W, Brann D and Mahesh V (2000) The potential role of periovarian fat and leptin in initiation of puberty in the immature rat International Journal of Obesity 24 S146-147

Caro JF, Sinha MK, Kolaczynski JW, Zhang PL and Considine RV (1996) Leptin: the tale of an obesity gene Diabetes 45 1455-1462

Castracane VD, Kraemer RR, Franken MA, Kraemer GR and Gimpel T (1998) Serum leptin concentration in women: effect of age, obesity and estrogen administration Fertility and Sterility $70472-477$

Chehab FF, Mounzih K, Lu R and Lim ME (1997) Early onset of reproductive function in normal female mice treated with leptin Science 275 88-90

Cioffi JA, Van Blerkom J, Antczak M, Shafer A, Wittmer S and Snodgrass HR (1997) The expression of leptin and its receptors in preovulatory human follicles Molecular Human Reproduction 3 467-472 
Cunningham MJ, Clifton DK and Steiner RA (1999) Leptin's actions on the reproductive axis: perspectives and mechanisms Biology of Reproduction $60216-222$

Duggal P, Van der Hoek K, Milner C, Ryan N, Armstrong D, Magoffin D and Norman R (2000) The in vivo and in vitro effects of exogenous leptin on ovulation in the rat Endocrinology 141 1971-1976

Gainsford T, Willson TA, Metcalf D, Handman E, McFarlane C, Ng A, Nicola NA, Alexander WS and Hilton DJ (1996) Leptin can induce proliferation, differentiation, and functional activation of hemopoietic cells Proceedings National Academy of Sciences USA 93 14 564-14 568

Gower BA, Nagy TR, Goran MI, Smith A and Kent E (2000) Leptin in postmenopausal women: influence of hormone therapy, insulin, and fat distribution Journal of Clinical Endocrinology and Metabolism 85 1770-1775

Haffner SM, Mykkanen L and Stern MP (1997) Leptin concentrations in women in the San Antonio Heart Study: effect of menopausal status and postmenopausal hormone replacement therapy American Journal of Epidemiology 146 581-585

Hardie L, Trayhurn P, Abramovich D and Fowler P (1997) Circulating leptin in women: a longitudinal study in the menstrual cycle and during pregnancy Clinical Endocrinology Oxford 47 101-106

Kalra S and Kalra P (1974) Temporal interrelationships among circulating levels of oestradiol, progesterone and LH during the rat oestrous cycle: effects of exogenous progesterone Endocrinology 95 1711-1718

Karlsson C, Lindell K, Svensson E, Bergh C, Lind P, Billig H, Carlsson LM and Carlsson B (1997) Expression of functional leptin receptors in the human ovary Journal of Clinical Endocrinology and Metabolism 82 4144-4148

Kitawaki J, Kusuki I, Koshiba H, Tsukamoto K and Honjo H (1999) Leptin directly stimulates aromatase activity in human luteinized granulosa cells Molecular Human Reproduction 5 708-713

Licinio J, Negrao AB, Mantzoros C et al. (1998) Synchronicity of frequently sampled, 24-h concentrations of circulating leptin, luteinizing hormone, and oestradiol in healthy women Proceedings National Academy of Sciences USA 95 2541-2546

Lord G, Matarese G, Howard L, Baker R, Bloom S and Lechler R (1998) Leptin modulates the T-cell immune response and reverses starvationinduced immunosuppression Nature 394 897-901

Lukaszuk K, Liss J, Kusiak E and Wojcikowski C (1998) Serum leptin concentration increases during luteal phase in healthy premenopausal women Hormone and Metabolic Research 303 172-173

McCowen KC, Chow JC and Smith RJ (1998) Leptin signaling in the hypothalamus of normal rats in vivo. Endocrinology $1394442-4447$

Machinal F, Dieudonne M, Leneveu M, Pecquery R and Giudicelli Y (1999) In vivo and in vitro ob gene expression and leptin secretion in rat adipocytes: evidence for a regional specific regulation by sex steroid hormones Endocrinology 140 1567-1574

Mannucci E, Ognibene A, Becorpi A, Cremasco F, Pellegrini S, Ottanelli S, Rizzello S and Massi G (1998) Relationship between leptin and oestrogens in healthy women European Journal of Endocrinology 139 198-201

Mercer JG, Moar KM, Rayner DV, Trayhurn P and Hoggard N (1997) Regulation of leptin receptor and NPY gene expression in hypothalamus of leptin-treated obese (ob/ob) and cold-exposed lean mice FEBS Letters 402 185-188

Mercer J, Moar K, Ross A, Hoggard N and Morgan P (2000) Photoperiod regulates arcuate nucleus POMC, AGRP and leptin receptor mRNA in Siberian hamster hypothalamus American Journal of Physiology $\mathbf{2 7 8}$ R271-281

Messinis IE, Milingos S, Zikopoulos K, Kollios G, Seferiadis K and Lolis D (1998) Leptin concentrations in the follicular phase of spontaneous cycles and cycles superovulated with follicle stimulating hormone Human Reproduction 13 1152-1156

Messinis I, Milingos S, Alexandris E, Kariotis I, Kollios G and Seferiadis K (1999) Leptin concentrations in normal women following bilateral ovariectomy Human Reproduction 14 913-918
Mistlberger RE, Lukman H and Nadeau BG (1998) Circadian rhythms in the zucker obese rat - assessment and intervention Appetite 30 255-267

Murphy B and Dobias M (1999) Homologous and heterologous ligands downregulate follicle-stimulating hormone receptor mRNA in porcine granulosa cells Molecular Reproduction and Development 53 198-207

Pescador N, Stocco D and Murphy B (1999) Growth factor modulation of steroidogenic acute regulatory protein and luteinization in the pig ovary Biology of Reproduction 60 1453-1461

Pickavance L, Tadayyon M, Williams G and Vernon RG (1998) Lactation suppresses diurnal rhythm of serum leptin Biochem and Biophysical Research Communications 248 196-199

Ruiz-Cortes Z, Men T, Palin M, Downey B, Lacroix D and Murphy B (2000) Porcine leptin receptor - molecular structure and expression in the ovary Molecular Reproduction and Development 56 465-474

Ryan NK, Van der Hoek KH and Norman RJ (2002) Expression of leptin and its receptor in the murine ovary: possible role in regulation of oocyte maturation Biology of Reproduction 66 1548-1554

Saladin R, De Vos P, Guerre Millo M, Leturque A, Girard J, Staels B and Auwerx J (1995) Transient increase in obese gene expression after food intake or insulin administration Nature 377 527-529

Santos-Alvarez J, Goberna R and Sanchez-Margalet V (1999) Human leptin stimulates proliferation and activation of human circulating monocytes Cellular Immunology 194 6-11

Schwartz MW, Peskind E, Raskind M, Boyko EJ and Porte D, Jr (1996) Cerebrospinal fluid leptin levels: relationship to plasma levels and to adiposity in humans Nature Medicine 2 589-593

Slieker LJ, Sloop KW, Surface PL, Kriauciunas A, LaQuier F, Manetta J, Bue Valleskey J and Stephens TW (1996) Regulation of expression of ob mRNA and protein by glucocorticoids and cAMP Journal of Biological Chemistry 271 5301-5304

Spicer LJ and Francisco CC (1997) The adipose obese gene product, leptin: evidence of a direct inhibitory role in ovarian function Endocrinology $1383374-3379$

Spicer LJ and Francisco CC (1998) Adipose obese gene product, leptin, inhibits bovine ovarian thecal cell steroidogenesis Biology of Reproduction 58 207-212

Stephens TW and Caro JF (1998) To be lean or not to be lean - is leptin the answer? Experimental and Clinical Endocrinology and Diabetes 106 $1-15$

Teirmaa T, Luukkaa V, Rouru J, Koulu M and Huupponen R (1998) Correlation between circulating leptin and luteinizing hormone during the menstrual cycle in normal-weight women European Journal of Endocrinology 139 190-194

Yoneda N, Saito S, Kimura M, Yamada M, lida M, Murakami T, Irahara M, Shima K and Aono T (1998) The influence of ovariectomy on ob gene expression in rats Hormone and Metabolic Research 30 263-265

Zachow RJ and Magoffin DA (1997) Direct intraovarian effects of leptin: impairment of the synergistic action of insulin-like growth factor-I on follicle-stimulating hormone-dependent oestradiol-17 beta production by rat ovarian granulosa cells Endocrinology 138 847-850

Zachow R, Weitsman S and Magoffin D (1999) Leptin impairs the synergistic stimulation by TGF-beta of $\mathrm{FSH}$-dependent aromatase activity and mRNA expression in rat ovarian granulosa cells Biology of Reproduction 61 1104-1109

Zhang Y, Olbort M, Schwarzer K, Nuesslein Hildesheim B, Nicolson M, Murphy E, Kowalski T, Schmidt I and Leibel R (1997) The leptin receptor mediates apparent autocrine regulation of leptin gene expression Biochemical and Biophysical Research Communications 240 492-495

Received 17 September 2001.

First decision 18 December 2001

Revised manuscript received 7 February 2002.

Accepted 14 February 2002. 